\title{
Evaluation and Empirical Study of Regional Innovation Ability Based on Five-Force Model
}

\author{
Wang Wanji ${ }^{1, a}$, HOU Renyong ${ }^{2, b,{ }^{*},}$, QIAO Wan ${ }^{3}$ \\ ${ }_{1,2,3}$ School of Management,Wuhan University of Technology, Wuhan ,Hubei,China \\ aemail: School8855@163.com, bemail: hourenyong@126.com
}

${ }^{*}$ Corresponding author

\begin{abstract}
Key words: Regional innovation, Evaluation of innovation ability, Index system
Abstract: With the implementation of national innovation-driven strategy, promoting regional innovation ability becomes the focus and emphasis of local economic development. The article constructs the evaluation index system about regional scientific and technological innovation from five dimensions including enterprise innovation ability, industrial driving force, environmental security capability, mechanism promoting force, social contribution ability. It uses a two-step method of comprehensive evaluation by calculating weights with coefficient of variation to evaluate innovation ability of 31 Provinces, and uses the factorial analysis method to conduct the correlation analysis for the 31 Provinces innovation ability from the endogenous function and explicit performance. Then a two-dimensional cluster analysis is conducted on this basis. Based on the results, suggestions for regional innovation ability to complete three changes are proposed. The first is to change from the theory of upward research focused on basic theories to the downward research focused on application development. The second is an organizational change from the individual decentralized innovation system to integrated systematic innovation system. The last one is the policy change from emphasizing innovative element inputs to emphasizing innovation mechanism.
\end{abstract}

\section{Introduction}

The concept of "innovation-driven" was put forward in the "Twelfth Five-Year Plan" in 2011, and the "innovation-driven endogenous growth" was taken as a new round of strategic objectives, which further demonstrated the importance of innovation in China's social and economic development. '11 According to the report of the 18th Party Congress in 2012, China is in an important period of economic transformation. Implementing the strategy of innovation-driven development, promoting innovation to catch up with global advances and continuously improving our capacity for making original innovation and for making further innovation on the basis of absorbing advances in overseas science and technology are inevitable for our country to accelerate the change of the growth model and increase the vitality and competitiveness of China's economy ${ }^{[2]}$; The 13th Five-Year Plan for Economic and Social Development put forward the implementation of the strategy of innovation-driven development. "Basing the fundamental point of development on innovation, taking scientific and technological innovation as the core and taking talent development as the support to promote the organic integration of scientific and technological innovation and public entrepreneurship innovation and shaping leading-edge development which relies more on innovation and has more advantages ". ${ }^{[3 】}$ The introduction of this series of policies is sending an important signal: innovation will definitely become the core driving force of China's economic development and innovation-driven strategy is an important engine of China's economic and social development.

Zhang Xiaodi (2008) argues that improving the capacity of independent innovation as well as resource utilization is the key point of innovation-driven development in China, while the the core of innovation-driven development is innovation of institutional mechanism, which means that GDP growth will no longer be the main evaluating indicator of government officials' performances and it will disperse the government's control over the allocation of resources and speed up the transformation of government functions ${ }^{[4]}$. Chen Xi (2013) claims that it's essential to establish a government-leading innovation subject system with enterprises as the main body, research 
institutions and scientific research personnel as sources of innovation and active participation of intermediaries. Meanwhile, the industrial cluster innovation platform, public service innovation platform and scientific and technological innovation investment and financing platform could be set as a material carrier and effective support for innovation-driven sustainable development ${ }^{[5]}$. Hong Yinxing (2013) states that through the original innovation, absorbing advances in overseas science and technology and collaborative innovation can gradually achieve independent innovation, achieve independent intellectual property rights of the core technology, and achieve changes from the exogenous development to the endogenous development ${ }^{[6]}$. Zhang Laiwu (2015) reckons that in the context of economic downturn, China's original way of development is accelerating the pace to the end, because the marginal effect of investment has already been very low and it has been difficult for our country to continue to bear the huge consumption of resources and environmental costs. Accelerating the development of the economy to the new normal with innovation-driven development and achieve a smooth transition and upgrade is not only urgent but also the only choice for China ${ }^{[7]}$.

Innovation-driven development has become a national strategy, which has been researched a lot by domestic scholars. For example, Li Hongwen ${ }^{[8]}$ focused on the importance of three elements including the slogan and action, development patterns and system on innovation-driven development. Wu You et al ${ }^{[9]}$ built an evaluation analysis framework from the four levels including impact of innovation, basic conditions, inputs and outputs. Mu Ruizhang [10] built a innovation-driven evaluation index system from three dimensions of the technology-driven ability, industry-driven ability and social-driven ability. Zhu Ying et al. [11] deconstructed the innovation-driven development as a coupling relationship between innovation and development. The integrated development level and the co-ordination degree can be used as a comprehensive evaluation scale of innovation-driven development performance.

Throughout the research at home and abroad, a systematic system has not yet established among China's research on innovation-driven development. Mainly from micro-individual level and different economic fields, research objects of domestic research are relatively dispersed, without in-depth analysis of the whole operation process of innovation and development. In the research of innovation ability evaluation, there is a lack of research on indicators including the impact of synergy of innovation factors on innovation ability, while most researches focus on inputs and outputs and other explicit indicators. Therefore, this paper will construct the evaluation index system of innovation ability, and analyze the innovation ability of our country empirically based on the endogenous function and explicit function perspective.

\section{Construction of Five-Force Model of Regional Innovation}

\subsection{Evaluation Index System}

At present, the regional innovation capacities of our provinces are uneven, and the influencing factors are embodied in two aspects: the core innovation ability and the mechanism promotion ability are different in each province; the external environmental security ability and social contribution ability of different provinces are different. Among them, the environmental security ability mainly refers to the financial environment, scientific and technology environment and the environment of intermediary organizations. The core innovation ability is mainly composed of two parts: enterprise innovation ability and industry driving ability. The social contribution ability mainly includes the economic contribution of regional innovation system and non-economic contributions such as employment, environmental protection and sustainable development. The mechanism promotion ability mainly refers to the interaction between the internal elements of innovation within the provinces and the flow of technology, reflecting the relationship between elements. Therefore, this paper designs the regional innovation capability evaluation system from five aspects: enterprise innovation ability, industrial driving ability, mechanism promotion ability, environmental security ability and social contribution ability, as it's shown in Table 1. 
Table 1 Innovation Ability Index System

\begin{tabular}{|c|c|c|}
\hline Primary Index & Secondary Index & Tertiary Index \\
\hline \multirow{7}{*}{$\begin{array}{l}\text { Enterprises } \\
\text { innovation } \\
\text { ability }\end{array}$} & \multirow{4}{*}{$\begin{array}{l}\text { research and } \\
\text { development of } \\
\text { enterprises }\end{array}$} & Number of researchers \\
\hline & & ratio of researchers to total number of employers \\
\hline & & Research and development funding \\
\hline & & ratio of research and development spending to total expenditure \\
\hline & \multirow{3}{*}{$\begin{array}{l}\text { Sales of new } \\
\text { products }\end{array}$} & Enterprise's technical innovation funding \\
\hline & & New product sales revenue \\
\hline & & Ratio of new product sales revenue to total revenues \\
\hline \multirow{5}{*}{$\begin{array}{l}\text { industrial } \\
\text { driving ability }\end{array}$} & \multirow{2}{*}{$\begin{array}{l}\text { Industry } \\
\text { compatibility }\end{array}$} & Industrial correlation \\
\hline & & Tertiary industry proportion \\
\hline & \multirow{3}{*}{$\begin{array}{l}\text { Industrial } \\
\text { innovation }\end{array}$} & High-tech industry output value \\
\hline & & Proportion of high-tech industry \\
\hline & & The industrial added value \\
\hline \multirow{8}{*}{$\begin{array}{l}\text { environmental } \\
\text { security ability }\end{array}$} & \multirow{4}{*}{$\begin{array}{l}\text { Technological } \\
\text { environment }\end{array}$} & Number of universities and research institutes \\
\hline & & Number of high quality publications \\
\hline & & Number of patents \\
\hline & & Number of major scientific research projects \\
\hline & \multirow{2}{*}{$\begin{array}{l}\text { Financial } \\
\text { environment }\end{array}$} & Total values of venture capital \\
\hline & & Foreign direct investment \\
\hline & \multirow{2}{*}{$\begin{array}{l}\text { Intermediate } \\
\text { environment }\end{array}$} & Number of incubators \\
\hline & & Number of national high-tech zones and economic development zones \\
\hline \multirow{5}{*}{$\begin{array}{l}\text { mechanism } \\
\text { promotion } \\
\text { ability }\end{array}$} & \multirow{2}{*}{$\begin{array}{l}\text { Cooperation } \\
\text { between the } \\
\text { elements }\end{array}$} & Universities and research institutes' development funds from enterprises \\
\hline & & $\begin{array}{cc}\text { proportion of funds } & \begin{array}{c}\text { from enterprises of universities and research } \\
\text { institutes }\end{array} \\
\end{array}$ \\
\hline & \multirow{3}{*}{ Technology flows } & $\begin{array}{l}\text { Technology transactions } \\
\end{array}$ \\
\hline & & $\begin{array}{c}\text { Expenditure on purchasing domestic technology of enterprises above } \\
\text { designated scales }\end{array}$ \\
\hline & & $\begin{array}{c}\text { Average expenditure on introcuding technology of enterprises above } \\
\text { designated scales }\end{array}$ \\
\hline \multirow{6}{*}{$\begin{array}{l}\text { social } \\
\text { contribution } \\
\text { ability }\end{array}$} & \multirow{3}{*}{$\begin{array}{l}\text { Economic } \\
\text { contribution }\end{array}$} & $\begin{array}{l}\text { Tax paid } \\
\end{array}$ \\
\hline & & Per capita GDP \\
\hline & & Total export \\
\hline & \multirow{3}{*}{$\begin{array}{l}\text { Non-economic } \\
\text { contribution }\end{array}$} & $\begin{array}{l}\text { Employment in high-tech industries } \\
\end{array}$ \\
\hline & & Proportion of employment in high-tech industries in total employment \\
\hline & & total energy consumption per million GDP \\
\hline
\end{tabular}

\subsection{Two-step Method of Comprehensive Evaluation by Calculating Weights with Coefficient of Variation}

For the convenience of evaluation, and elimination of the impact of subjective factors as far as possible, this paper uses a two-step evaluation method. First, we use the coefficient of variation to determine the weights of each index, and calculate the comprehensive utility value of each province in the use of weighted comprehensive evaluation method. Then we sort the values according to the final utility value.

(1) Calculating weights--- Coefficient of variation method

In this paper, the Coefficient of variation method is used to calculate the weights of the indexes directly by using the information contained in each index. The method is an objective way of weighting. The basic principle of this method is: in the evaluation index system, it's not proper to compare the degree of differences directly because the indicators of the evaluation index system have different dimensions. In order to eliminate the different effects of the evaluation index, the coefficient of variation of each index needs to be used to measure the difference in the value of each index. 
Suppose that the set of $\mathrm{n}$ schemes to be evaluated is a set of evaluation factors. Multiply each of the schemes in $\mathrm{u}$ by each factor in $\mathrm{v}$ to obtain the observation matrix $\mathrm{A}=$, which represents the jth scheme for the evaluation of the $i$-th evaluation index value. The vector represents the evaluation vector of the jth scheme for the $m$-th evaluation index.

The formula of coefficient of variation for each index is as follows:

$$
V_{i}=\frac{\sigma_{i}}{\bar{x}_{i}}(i=1,2, \cdots, n)
$$

In the formula: $V_{i}$ is the coefficient of variation, or the standard deviation coefficient of the i-th index; $\sigma_{i}$ is the standard deviation of the i-th index. The formula is: $\bar{x}_{i}$ is the index of the average number of the $i$-th index. The formula is...

After the normalization process of $V_{i}$, we can draw the weights of indicators:

$$
W_{i}=\frac{V_{i}}{\sum_{i=1}^{n} V_{i}}
$$

(2) Indicator Evaluation-- Weighted Synthesis Method

Weighted calculation is a hierarchical calculation. As it's shown in Picture 1, a b, c, d stand for four layers respectively, and $\mathrm{f}(\mathrm{a}), \mathrm{f}(\mathrm{b})$... stand for weights of indexes calculated the coefficient of variation. $x(a, i) 、 x(b, i)$ stands for utility values of indicators in each layer and each parts. Calculation should be conducted from right to left.

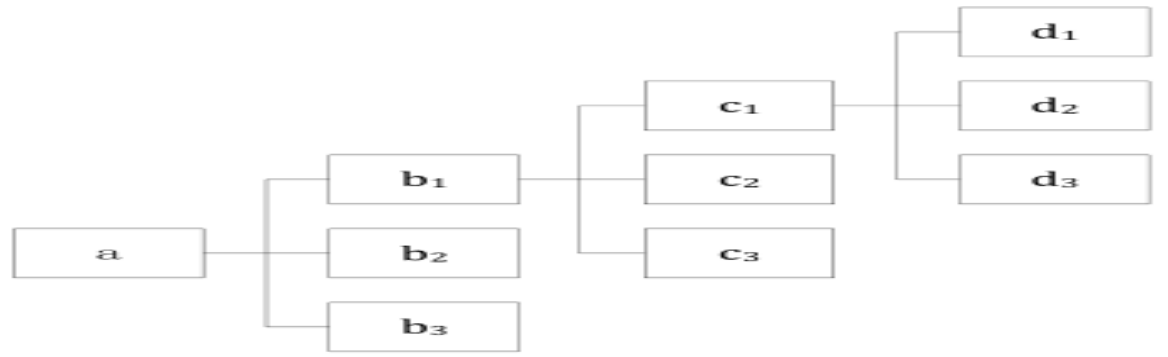

Figure 1. a b, c, d stand for four layers respectively

For example, to calculate index value of ci, we should set $\mathrm{x}(\mathrm{ci}, \mathrm{i})$ as comprehensive utility value of zone $i$ in the index ci, and $x(d i, i)$ as comprehensive utility value of zone $i$ in the index di. Then,

$$
x\left(\mathrm{c}_{1}, \mathrm{i}\right)=\sum_{1}^{n} x\left(\mathrm{~d}_{\mathrm{i}}, \mathrm{i}\right) f\left(\mathrm{~d}_{\mathrm{i}}\right)
$$

$x(c 2, i), x(c 3, i), \ldots$ can be calculated in the same manner.

And then calculating $\mathrm{x}(\mathrm{bi}, \mathrm{i})$

$$
x\left(\mathrm{~b}_{1}, \mathrm{i}\right)=\sum_{1}^{n} x\left(\mathrm{c}_{\mathrm{i}}, \mathrm{i}\right) f\left(\mathrm{c}_{\mathrm{i}}\right)
$$

$\mathrm{x}(\mathrm{b} 2, \mathrm{i}), \mathrm{x}(\mathrm{b} 3, \mathrm{i}), \ldots$ can be calculated in the same manner.

And then calculating $x(a, i)$ :

$$
x(\mathrm{a}, \mathrm{i})=\sum_{1}^{n} x\left(\mathrm{~b}_{\mathrm{i}}, \mathrm{i}\right) f\left(\mathrm{~b}_{\mathrm{i}}\right)
$$

Calculate utility values or 21 provinces in each layer and of each index by setting $\mathrm{i}$ as $1,2, \ldots, 31$ respectively. 


\section{Empirical Demonstration of Innovation Ability of China's 31 Provinces}

According to the above evaluation index system and evaluation method, a total of 31 indicators of 31 provinces and cities in 2014 are evaluated and analyzed.

\subsection{Evaluation Result of Regional Innovation Ability}

As shown in Table 3, Jiangsu, Guangdong, Beijing, Shanghai and Zhejiang ranked the top five respectively, with relatively strong comprehensive innovation abilities. Except for Chongqing and Anhui, the remaining eight seats of top ten were the eastern coastal provinces. Except for Hebei, the last ten are all from the western region, indicating that the overall level of innovation in the western region is low. Central region and northeast region are in the middle of the ranking.

Table 2 Innovation Ability Evaluation of 31 Provinces

\begin{tabular}{|c|c|c|c|c|c|c|c|c|c|c|c|c|}
\hline \multirow[t]{2}{*}{ Province } & \multicolumn{2}{|c|}{$\begin{array}{l}\text { Comprehensi } \\
\text { ve value }\end{array}$} & \multicolumn{2}{|c|}{$\begin{array}{c}\text { Enterprises } \\
\text { innovation } \\
\text { ability } \\
\end{array}$} & \multicolumn{2}{|c|}{$\begin{array}{l}\text { industry driving } \\
\text { ability }\end{array}$} & \multicolumn{2}{|c|}{$\begin{array}{c}\text { mechanism } \\
\text { promotion } \\
\text { ability }\end{array}$} & \multicolumn{2}{|c|}{$\begin{array}{l}\text { environmental } \\
\text { security ability }\end{array}$} & \multicolumn{2}{|c|}{$\begin{array}{c}\text { social } \\
\text { contribution } \\
\text { ability }\end{array}$} \\
\hline & $\begin{array}{l}\text { Utility } \\
\text { value }\end{array}$ & $\begin{array}{l}\text { Ran } \\
\text { king }\end{array}$ & $\begin{array}{l}\text { Utility } \\
\text { value }\end{array}$ & $\begin{array}{c}\text { Rank } \\
\text { ing }\end{array}$ & $\begin{array}{l}\text { Utility } \\
\text { value }\end{array}$ & $\begin{array}{c}\text { Ranki } \\
\text { ng }\end{array}$ & $\begin{array}{l}\text { Utility } \\
\text { value }\end{array}$ & $\begin{array}{c}\text { Ranki } \\
\text { ng }\end{array}$ & $\begin{array}{l}\text { Utility } \\
\text { value }\end{array}$ & $\begin{array}{c}\text { Ranki } \\
\text { ng }\end{array}$ & $\begin{array}{l}\text { Utility } \\
\text { value }\end{array}$ & $\begin{array}{c}\text { Rank } \\
\text { ing }\end{array}$ \\
\hline Weight & \multicolumn{2}{|l|}{1} & \multicolumn{2}{|c|}{0.25} & \multicolumn{2}{|c|}{0.15} & \multicolumn{2}{|c|}{0.15} & \multicolumn{2}{|c|}{0.25} & \multicolumn{2}{|c|}{0.2} \\
\hline Jiangsu & 57.57 & 1 & 72.23 & 1 & 47.77 & 2 & 60.53 & 2 & 48.66 & 2 & 55.53 & 2 \\
\hline Guangdong & 52.98 & 2 & 60.54 & 2 & 43.66 & 3 & 40.38 & 4 & 49.28 & 1 & 64.58 & 1 \\
\hline Beijing & 50.73 & 3 & 49.7 & 5 & 69.68 & 1 & 48.71 & 3 & 48.26 & 3 & 42.42 & 5 \\
\hline Shanghai & 47.18 & 4 & 49.61 & 6 & 42.7 & 4 & 62.26 & 1 & 37.68 & 5 & 48.08 & 3 \\
\hline Zhejiang & 42.40 & 5 & 59.63 & 3 & 32.51 & 5 & 31.68 & 8 & 37.76 & 4 & 42.12 & 6 \\
\hline Shandong & 37.65 & 6 & 50.02 & 4 & 27.39 & 8 & 30 & 10 & 34.23 & 6 & 39.88 & 8 \\
\hline Tianjin & 36.13 & 7 & 42.94 & 7 & 23 & 12 & 36.16 & 7 & 29.43 & 9 & 45.82 & 4 \\
\hline Chongqing & 33.88 & 8 & 38.76 & 8 & 26.38 & 10 & 39.13 & 5 & 24.45 & 16 & 41.26 & 7 \\
\hline Anhui & 29.76 & 9 & 37.79 & 9 & 22.8 & 14 & 16.92 & 27 & 31.64 & 7 & 32.2 & 19 \\
\hline Fujian & 29.33 & 10 & 32.09 & 11 & 18.76 & 19 & 26.73 & 11 & 28.34 & 10 & 36.99 & 11 \\
\hline Liaoning & 28.85 & 11 & 25.96 & 14 & 23.14 & 11 & 39.07 & 6 & 25.13 & 15 & 33.75 & 17 \\
\hline Hubei & 28.71 & 12 & 29.78 & 12 & 22.88 & 13 & 22.86 & 15 & 30.82 & 8 & 33.47 & 18 \\
\hline Hunan & 28.25 & 13 & 34.9 & 10 & 20.2 & 17 & 18.71 & 22 & 26.24 & 13 & 35.65 & 13 \\
\hline Shaanxi & 27.67 & 14 & 25.86 & 15 & 31.94 & 6 & 22.85 & 16 & 26.26 & 12 & 32.13 & 20 \\
\hline Sichuan & 27.16 & 15 & 22.83 & 20 & 26.74 & 9 & 23.75 & 14 & 26.99 & 11 & 35.66 & 12 \\
\hline Henan & 26.21 & 16 & 23.79 & 16 & 21.43 & 15 & 18.01 & 23 & 26.18 & 14 & 39.02 & 9 \\
\hline Hainan & 24.10 & 17 & 22.13 & 23 & 30.65 & 7 & 11.42 & 30 & 23.37 & 19 & 32.07 & 21 \\
\hline $\begin{array}{c}\text { Inner } \\
\text { Mongolia } \\
\end{array}$ & 23.74 & 18 & 17.86 & 29 & 12.42 & 31 & 30.64 & 9 & 23.74 & 18 & 34.38 & 16 \\
\hline $\begin{array}{c}\text { Heilongjian } \\
\mathrm{g}\end{array}$ & 23.55 & 19 & 27.21 & 13 & 17.9 & 22 & 23.9 & 13 & 19.83 & 29 & 27.58 & 26 \\
\hline Jiangxi & 23.53 & 20 & 19.52 & 27 & 17.31 & 25 & 22.46 & 17 & 23.18 & 20 & 34.46 & 14 \\
\hline Guangxi & 23.07 & 21 & 23.35 & 17 & 17.93 & 21 & 17.87 & 25 & 22.94 & 22 & 30.62 & 22 \\
\hline Hebei & 23.00 & 22 & 22.26 & 22 & 18.56 & 20 & 22.35 & 18 & 20.85 & 26 & 30.44 & 23 \\
\hline Jilin & 22.64 & 23 & 21.11 & 24 & 15.27 & 27 & 17.19 & 26 & 22.44 & 24 & 34.42 & 15 \\
\hline Guizhou & 22.60 & 24 & 20.69 & 25 & 18.78 & 18 & 21.76 & 19 & 23.98 & 17 & 26.76 & 27 \\
\hline Gansu & 22.20 & 25 & 23.15 & 18 & 17.37 & 24 & 25.83 & 12 & 19.73 & 30 & 25.02 & 29 \\
\hline Shanxi & 21.68 & 26 & 23.06 & 19 & 15.14 & 29 & 21.21 & 20 & 18.69 & 31 & 28.97 & 24 \\
\hline Yunnan & 21.32 & 27 & 19.86 & 26 & 17.55 & 23 & 20.77 & 21 & 22.34 & 25 & 25.13 & 28 \\
\hline Xinjiang & 20.38 & 28 & 18.41 & 28 & 20.33 & 16 & 13.61 & 28 & 20.17 & 28 & 28.24 & 25 \\
\hline Ningxia & 20.32 & 29 & 22.48 & 21 & 16.76 & 26 & 17.97 & 24 & 22.58 & 23 & 19.23 & 31 \\
\hline Qinghai & 17.65 & 30 & 14.63 & 30 & 12.87 & 30 & 13.09 & 29 & 23.09 & 21 & 21.61 & 30 \\
\hline Tibet & 17.23 & 31 & 3.16 & 31 & 15.21 & 28 & 9.2 & 31 & 20.64 & 27 & 38.09 & 10 \\
\hline
\end{tabular}




\subsection{Relevance Analysis of Innovation Capability}

In order to further understand the status of innovation ability in each province, the index system established above is divided into two dimensions: endogenous function and innovation performance. The author will analyze the regional innovation ability and find out its development constraints.

(1) Correlation analysis

$\mathrm{Y}=1.69 \mathrm{X}$

First, the data of Table 3 are processed according to the comprehensive weighting method, to obtain the comprehensive utility value of endogenous function, and then the regression analysis is carried out with the innovative performance utility value. According to the results, the judgment coefficient of the goodness test is 0.636 in the regression analysis, so the regression can be fitted. The $\mathrm{T}$ test value of the regression coefficient is $\mathrm{P}<0.001$, which indicates that the regression coefficient is not zero and the established regression model is statistically significant. In the residual $\mathrm{T}$ test, $\mathrm{P}=0.8>0.05$, indicating that the constant term is not significantly different from zero. According to the results, the regression equation is:

$\mathrm{Y}=1.69 \mathrm{X}$

The results show that the endogenous function has a strong positive correlation with the innovation performance.

(2) Double Cluster Analysis

Since the endogenous function is related to the innovation performance, the analysis of the innovation ability can be double clustered according to the two dimensions. We set the number of clusters as 4, and indicate the relative capacity of each province in the coordinate system. From the perspective of endogenous function, Jiangsu, Beijing and Guangdong are the strongest, Shanghai, Shandong, Tianjin, Chongqing and Zhejiang are in the second category. The third category includes Anhui, Fujian, Liaoning and Hubei province, etc. The remaining provinces are all in the fourth category. From the aspect of innovation performance, the strongest one is Jiangsu, Shanghai, Beijing, Zhejiang, Guangdong, etc are in the second category. Hubei, Fujian, Anhui, Liaoning, Shandong, Tianjin, Chongqing are in the third category, and the remaining provinces are in the fourth category. As it can be seen from Figure 2, provinces in categories of 1, 3, 5, 6 have more balanced endogenous functional and innovative performance development, while provinces in categories of 2 and 4 don't have a coordinated development of the two strengths. Overall, the development of innovation capacity in most provinces of our country is balanced but the overall strength is weak. 


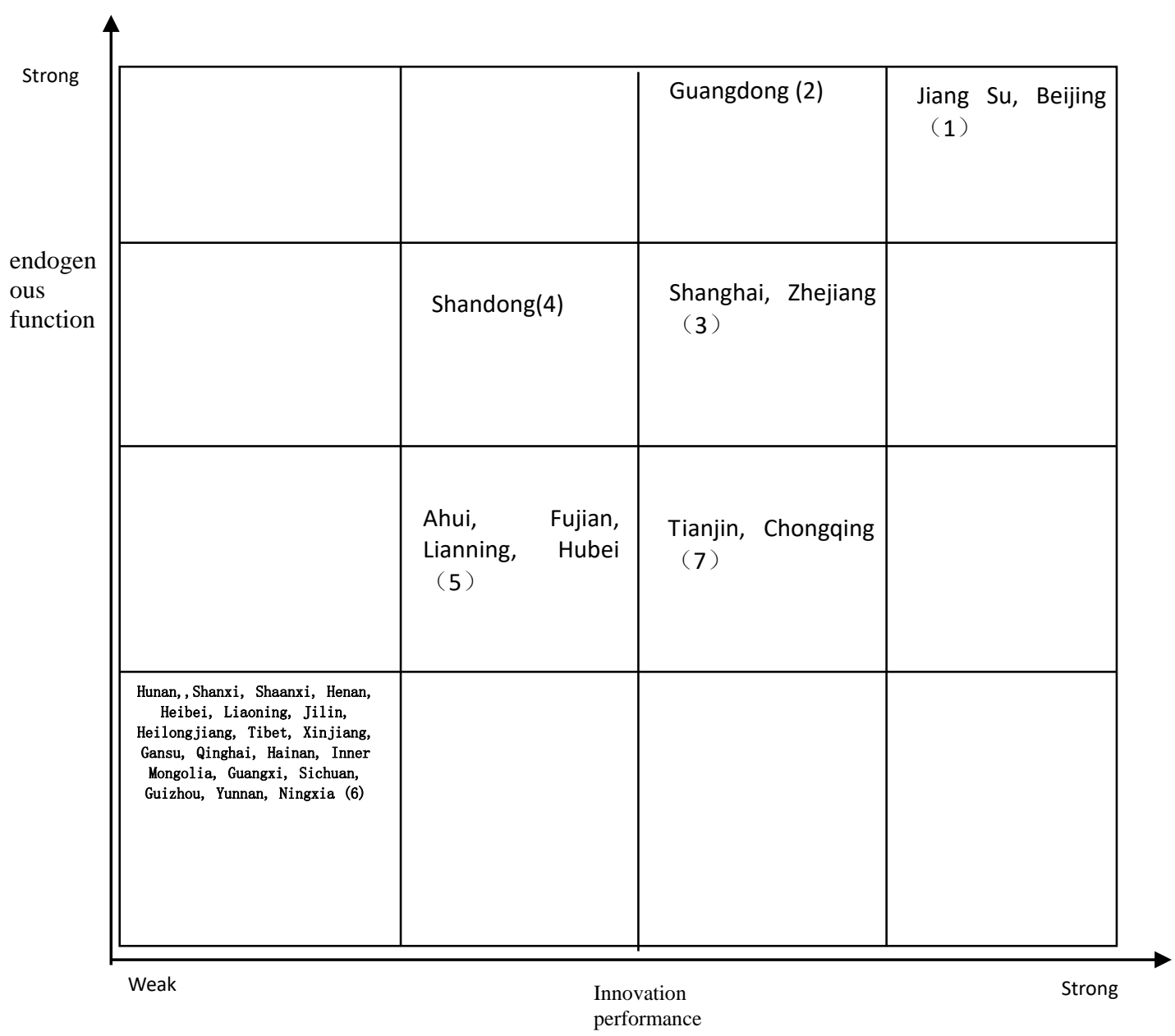

Fig. 2 Double Cluster Analysis

\section{Suggestions}

Based on present situation of innovation capacity development in our country, it's urgent for each province and city to complete three transformations of the regional innovation ability. The first is to change from the theory of upward research focused on basic theories to the downward research focused on application development. The second is an organizational change from the individual decentralized innovation system to integrated systematic innovation system. The last one is the policy change from emphasizing innovative element inputs to emphasizing innovation mechanism.

\subsection{Change from the theory of upward research focused on basic theories to the downward research focused on application development}

Basic scientific research is the source of scientific and technological development and the position to create high-quality innovative talents. Aimed at the forefront of national innovation strategy development, being in the upper reaches of the entire innovation chain, and getting an important position in the construction of scientific and technological innovation system are the important foundation and premise of upgrading independent innovation ability and achieving regional innovation and development. From the perspective of process of regional innovation and development, innovation is the researching process of investing innovative resources into knowledge, and the process of forming social innovation environment through the transformation and application of research and development results as well as implantation of innovation into economic and social development. In this process, the application of the results and diffusion is the central link, as well as the link of basic research results and economic and social development. Therefore, it is necessary to realize the change from the theory of upward research focused on basic 
theories to the downward research focused on application development. While focusing on the research of the basic theory of innovation, we can realize the breakthrough of the downward research focused on application development and achieve regional innovation and development by transforming the basic theoretical research into scientific and technological productivity.

\subsection{Organizational change from the individual decentralized innovation system to integrated systematic innovation system}

Innovative activities are mainly carried out in decentralized technological innovation systems and knowledge innovation systems formed by enterprises, universities, research institutes, governments, science and technology intermediary service organizations and other organizations. With enterprises as main bodies, the main goal of technological innovation system is to realize the commercialized technological innovation, in pursuit of the value of innovation achievement in the field of application innovation. The technology intermediary service organization mainly provides the designs, pilots, consulting services as well as innovation equipment for technological innovation enterprises. Financial institutions mainly provide loans for innovative enterprises. The core of knowledge innovation system includes universities and research institutes, whose main goal is to achieve theoretical innovation, in pursuit of the value of innovation achievement in the field of basic research. As each innovation system has different goals and pursuit of value, it is difficult for the individual decentralized innovation system to form synergies between the organizations. Innovation requires innovative organizations to build an integrated innovation system, forming a systematic synergy and playing collaborative effects. Integrated innovation system sets the main structure with five integrated factors of "government, production, education, research, and financial system", with support of three main platforms including knowledge innovation platform, technology innovation platform and science and technology innovation intermediary service platform, so as to form a comprehensive management mode with integrated systematic innovation system.

\subsection{Policy change from emphasizing innovative element inputs to emphasizing innovation mechanism}

Currently, regional innovation is mostly of top-down government-leading model. Mainly through increasing inputs of funds in innovative elements, the government-leading model is to form of a short-term investment-driven effect and to create an environment conducive to innovation. This approach can quickly show its effects of investment, and form a late-mover advantage in the short term. However, this approach requires large investment of capital but can only produce a small amount of innovation output, resulting in a low innovative efficiency. What's worse, colleges and universities, research institutes and innovative enterprises may even spend excessive energy on fighting for more government innovation funds, which is called a dilemma of "fighting for funds instead of innovation". At the same time, the approach to guide the innovation through the element investment remains many problems in terms of unreasonable internal mechanisms, slow construction of soft environment, lack of long-term power of innovation and lack of long-term security. Therefore, it's necessary to make changes in terms of promotion of innovation and development policies, which includes the change from a single financial support to a series of policies aiming to construct a long-term mechanism and the policy change from emphasizing innovative element inputs to emphasizing innovation mechanism. Constructing a set of mechanisms conducive to innovation through the changes, coping with the dilemma of "fighting for funds instead of innovation" with effective guide of innovative institutional mechanisms can promote effective allocation of innovative elements in the region and create a resources distribution system with fairness and justness, high quality and efficiency.

\section{References}

[1]The Twelfth Five-Year Plan for National Economic and Social Development of the People's Republic of China [M].Beijing: People's Publishing House, 2011. (in Chinese)

[2]Report to the Eighteenth National Congress of the Communist Party of China: Firmly March on the Path of Socialism with Chinese Characteristics and Strive to Complete the Building of a 
Moderately Prosperous Society in All Respects, 2012. (in Chinese)

[3]The Thirteenth Five-Year Plan for National Economic and Social Development of the People's Republic of China [M]. Beijing: People's Publishing House, 2016. (in Chinese)

[4]Zhang Xiaodi. Theory and Practice of Innovation Drive in the Economy Changing Growth Mode [J]. Economic Research Guide, 2008,(3):101-120. (in Chinese)

[5]Chen Xi, Path of Innovation-driven Development Strategy Selection [J].On Economic Problems,2013.(5):29-39. (in Chinese)

[6]Hong Yinxing. On the Innovation-Driven Economic Development [J].Beijing, Economist, 2013, (7):122-139. (in Chinese)

[7]Zhang Laiwu. A Theoretical Thinking and Practical Exploration on the Innovation-driven Urban

- Rural Integration [J].China Soft Science, 2015,(4):1-7. (in Chinese)

[8]Li Hongwen. Study of China's Innovation Drive to Development and Countermeasure [J]. Scientific Management Research，2013， 1(3): 26-29 (in Chinese)

[9]Wu You, Li Wenjiang, Ding Hua, et al. On an Indicator System for Innovation Driven Development [J]. China Opening Journal, 2014(4): 88-92 (in Chinese)

[10]Mu Ruizhang. Research on Innovation-driven Evaluation of Small and Medium-sized Technology-based Enterprises in Tianjin [J]. Tianjing Economy, 2015, (3): 71-74 (in Chinese) [11]Zhu Ying, Wang Fei. Study on the Evaluation of China Provincial Innovation-driven Development Based on Coupling Theory [J]. Chinese Journal of Management, 2016,13(10): 1509-1517 (in Chinese) 